\title{
INFLUENCE OF COMPETENCE, TRANSFORMATIONAL LEADERSHIP, SOCIAL CAPITAL AND PERFORMANCE ON EMPLOYEE CAREERS
}

\author{
Nia Kusuma Wardhani \\ Mercubuana University \\ nia.wardhani77@gmail.com
}

\begin{abstract}
Every employee would expect a career enhancement in his job. There are many factors that affect employee careers. This study aims to examine the influence of Competence, Transformational Leadership, Social Capital and Performance to Career Employees of Mercu Buana University, is a quantitative research with Path Analysis method. This research was conducted at Mercu Buana University in West Jakarta area, the research sample was 185 employees using Simple Random Sampling method. Associated with the performance of employees, the results showed that there is an influence of competence on performance, there is the influence of transformational leadership on performance, there is the influence of social capital on performance. In the case of employee career, the result of research indicate that there is influence of competence to career of employee, there is influence of employee career performance, there is influence of social capital to career of employee. The result of path analysis gives a structural equation $Y=0,258 X 1+0,213 X 2+0,229 X 3+0,416 X 4$ $+0,36$. Thus it can be explained that the most direct influence on Employee Career is a Performance variable of $41.6 \%$, while the Competence variable of $25.8 \%$ and social capital variable of $22.9 \%$.
\end{abstract}

\section{Keywords:Competence,Transformational Leadership, Social Capital, Performance,Careers}

As the organization grows and develops in the dynamics of globalization, the need for quality human resources increases. Employee is a valuable asset for the University of Mercu Buana, so should be increased competence and productivity in order to perform well. In addition, it is necessary to support management to improve employee career.

Ivancevich and Konopaske define Human Resource Management as an organizational function that facilitates employees to achieve individual goals and organizational goals. Dessler defines Human Resource Management as a policy and practice that an employee requires through employee recruitment, selection / screening, training, rewards / rewards, and job appraisal.

As an individual, employees are social beings who have a network of friends both internal and external organizations, this is the social capital owned by employees and has the potential to improve performance and career because it has a link to build communication and cooperation among employees who contribute in building the organization.

Success or failure of the organization to achieve its objectives is determined by the ability of the leadership to move the members of the organization. The ability and leadership skills to direct is an important factor in managers effectiveness. In striving the organization to achieve its goals with high work productivity, leaders motivate subordinates to improve coordination so that inter-unit cooperation is established by considering the effective aspects and work efficiency. Transformational leadership is a leadership style applied at the University of Mercu Buana to quickly respond to change, oriented improvement in everything field, achievement and dynamic and flexible in the face of competition so that can grow rapidly improve the quality of service to its stakeholders in the era of globalization. This is evidenced by the Accreditation of Institutional Institutions of Higher Education with the predicate $\mathrm{A}$.

Based on the results of observations of researchers and interviews to employees, found problems in employee careers. Employees also lack the information about career. Sometimes even if there is an empty position, filled from the path of acceptance of new employees so that employees 
who have the potential and experience are not placed in that position. No employee rotation is applied periodically resulting in boredom and even job saturation because employees do the same job for long periods of time. While the training provided to employees tend to be internal only and the process of dissemination of training results in terms of knowledge and know how was not entirely running smoothly as expected.

Given that the importance of employee competence as an organizational asset, the role of the leader responsive to the dynamics of the organizational environment and employee social capital that can support employee performance it is appropriate that the organization gives attention to the employee's career so that employees are more motivated to work better.Maka researchers want to research more far about the employee's career variables are influenced by the competence of employees, performance and social capital and how the influence of competence, leadership style transformational, and social capital of employees to their performance.

Thus can be determined independent variables in this study are competence, transformational leadership and social capital, while the dependent variable in this study is the performance and career of employees.

\section{Employee Career (Y)}

Noe believes that those who succeed in careers are those who continue to perform well. The willingness to sacrifice for the company is also needed (such as accepting new tasks or moving to different areas). Good oral and written communication skills, ease in interpersonal relationships, and talent for leadership are essential.

Cascio argues that the word career can be viewed from two different perspectives, among others from an objective and subjective perspective. Viewed from an objective perspective, a career is a sequence of positions occupied by a person during his life, while from a subjective perspective, a career is a change in values, attitudes, and motivations that occur because someone becomes older.

According to Sutanto, there are three factors that are considered important for career success, among others, can put themselves in a precise condition, without sacrificing the principle of life; dare to face the risks and challenges with full responsibility; and able to communicate seamlessly with various parties.

Moeheriono explains the notion of a career is a process a person during work, there are ways and pathways to develop it. In general, qualified companies always strive to create a clear career ladder in accordance with the capacity, quality and dedication of employees for the contribution and excellent performance. A career is part of one's journey and purpose.

According to Tohardi, a career is the level of position (occupation) that had been held by someone during the person working in the organization or company. There are five factors that affect whether or not an employee's career, namely: Attitude of boss and co-worker, experience, education, achievement and fate factors.

Bernardin dan Russel (2013), berpendapat bahwa "career is an individually perceived sequence of attitudes and behaviours associated with work-related activities an experiences over the span of person's life."

According to Greenhaus, "a career is a pattern of work-related experiences and activities over the spen of the persons work life."

Career is a perception of attitudes and behavior regarding the order of positions or occupations occupied during one's working life, as a pattern of systematic progress and there is a pathway to develop it. Career is a need that must be grown in an employee, so as to encourage his willingness to work. One's career can be developed through the interaction between individual abilities and organizational needs. This is done by creating conditions and career development opportunities as well as adjusting to the needs of the organization through personal mutations (rotation). 
According to Ruky, career advancement is often the obsession of many people who work and often more into their minds than the leadership of the company / organization. Career development is also the responsibility of both parties (organizational and employee management). Those who have the vision and ambition to develop a career should always take the initiative and action that will help develop his career

The human resources department should seek management support, provide feedback to employees and build a cohesive work environment to enhance employees' abilities and desires in carrying out career development. Feedback has the purpose of ensuring non-promoted employees that they are still valuable and will be considered for further promotions if they are qualified.

It can be synthesized that careers are essentially a number of work positions held by a person based on work experience and the results of his education and activities throughout the course of a person's working life. The significant indicators of career are interest promoted, can adapt, known (exposure), can communicate well

\section{Competence (X1)}

Consideration of competency needs includes future demand in relation to the organization's strategic and operational plans and objectives; anticipate the need for change of management and employees; Changes to processes and technology and organizational equipment; evaluation of the competence of employees in carrying out the activities and processes established. Competence analysis is largely devoted to career development, but determining the level of competence is required to determine the expected effectiveness of the performance level.Competence lies in the inner part of every human being and forever exists in the personality of a person who can predict behavior and performance extensively on all work situations and tasks.

According Wibowo, competence is an ability to perform or perform a job or task based on skills and knowledge and supported by the work attitude demanded by the job.

According to Spencer in Moeheriono, competence is defined as the underlying characteristic of a person with regard to the effectiveness of the performance of an individual who has a causal relationship or as a cause-effect that is used as a benchmark, effective and superior performance in the workplace or in certain situationsThe indicators are motive, trait, self concept, skill and knowledge.

Mangkunegara defines the competence of human resources is the competence associated with knowledge, skills, abilities and personality characteristics that directly affect the performance.

At the University of Mercu Buana, employees must also have special competencies such as the ability of the field of computers in order to use information systems academic-based Information Technology. In terms of personality characteristics, employees must be able to adapt to the dynamics of their working environment and establish good relationships with other employees, lecturers and students.

According to Scale, competence comes from the word competence which means skill, ability and authority. Furthermore Boulter, Dalziel and Hill, argued competence is a basic characteristic of a person who allows it to deliver superior performance in a particular job, role or situation.

Hutapea and Thoha argue that people who have competence are people who have better performance than their colleagues, able to interact and adapt to the work environment or business environment, able to face the challenges of work and have consistency in achievement.

According to Spencer, the main component of the formation of competence is knowledge, skill and attitude.Sedangkan self concept, Trait and Motive are more likely to affect one's behavior.

Wibowo also argues that the strata of competence include: core competencies, managerial competencies, and functional competencies.

In terms of developing competence, it is necessary to anticipate and overcome various obstacles faced. Michael Zwell mentioned the factors that can be used to improve competence, 
namely: admitting incompetence, Raising Expectations, Identifying Barriers, Including Support Mechanism from management.

Based on the opinions of the experts above, it is synthesized that competence is the ability of a person to perform the work supported by the skills, knowledge, and working attitude needed to achieve success in his work. Thus, the competency indicator is: Knowledge, Skill, Attitude, Self Control, Self Confidence, Flexibility, Building Relationship.

\section{Transformational Leadership (X2)}

To realize the goals of the organization required a reliable leader, able to bring the organization in achieving its vision and mission. According Moeheriono, this also requires the organization always open up to adjust to changes in both internal and external environment. This means the organization must be able to formulate strategies and policies that quickly, accurately and effectively to overcome any such changes.

In the results of his research Mukhtar et al explains that the style of leadership is the way leaders in directing subordinates where it also affects the career development of employees. So 'Likes and Dislikes' is an unavoidable factor and should be an individual concern if you want to succeed in his career.

The process of leadership in the organization occurs because of the elements of leaders and subordinates as people / groups that led. According to Drucker, states that "leaders are individuals who make things happen. It is what makes something into something itself. Make the organization into a real organization ".

According to David Wilkins and Greg Carolin, "Leadership is rooted in the ability to think critically, instill such practices in others, and engage the entire organization in critical and aligned thinking in the areas of strategy, innovation and implementation". Leadership is rooted in the ability to think critically, apply it to others, and engage the entire organization in critical ways and align its thinking in terms of strategy, innovation and implementation.

Meanwhile, according to Hughes, Ginnet, Curphy: Leadership is a complex phenomenon involving leaders, followers and situations. Some researchers on leadership focus on the personality, physical character or behavior of the leader.

Transformational leadership comes from the Transform word which means to transform something into a different form. A Transformational leader must be able to transform (change) optimally the organizational resources in order to achieve meaningful goals in accordance with predetermined targets. These resources can be employees, facilities, funds, and external factors organization. Transformational leadership is particularly concerned with the idea of improvement in all fields.

It was later asserted by Burns that transformational leadership must be able to define, communicate and articulate the vision and mission of the organization.

Avolioet al proposes that transformational leaders behave in a way that achieves superior results by emphasizing one or more of the four dimensions of transformational leadership. First, leadership is idealized as followers seek to identify with their leaders and imitate them. Second, leadership inspires followers with challenges and persuasion that give meaning and understanding. Third, intellectual leadership stimulates, expands the use of followers from their abilities.

Yukl argues that transfomational leadership involves internalization because inspirational motivation involves the pronunciation of an intriguing vision that links the task objective to the values and idealism of followers reflected in the organizational culture. Its inaugurators are leaders trying to transform and motivate their subordinates by making them more aware of the importance of work results, encouraging them to put more importance on the organization or team rather than selfinterest, and activating their needs on a higher level. 
A leader is said to be transformational when it can change the situation, change what is commonly done, talk about a lofty goal, have a reference to the value of freedom, justice and equality. The transformational leader will make the subordinate see that the goal to be achieved is more than just his personal interests.

To raise the consciousness of his subordinates in order to work better, the transformational leadership style is always related to subordinates by emphasizing moral values.

The transformational leader always seeks to motivate his subordinates to do more than the expected standard of output. Leaders will set higher targets with the goal of achieving high performance in a better way. This is in line with the opinion of Esther et al that the concept of transformational leadership consists of charisma (ideal influence), inspirational motivation, intellectual stimulation, and individual considerations.

Bass states that transformational leadership provides a vision and a sense of mission, instilling pride and profit, respect and trust.

It can be synthesized that transformational leadership is a process of interaction involving all organizations where charismatic leaders seek to influence, motivate employees and apply critical thinking through intellectual stimulation, individual considerations and moral values so that employees improve their performance and optimize all organizational resources to achieve goals with results that exceed the standards / expectations (breakthrough result). The significant indicators of transformational leadership are Ideal Influence, Inspirational, Individual Considerations, Intellectual Stimulation

\section{Social Capital (X3)}

Social capital is a resource that can be viewed as an investment to acquire new resources. Social capital exists in relationships where trusts, norms (shared values and behaviors) link the network of its members (network), which creates cooperation.

According to Tb.Sjafri Mangkunegara, social capital in the organization is characterized by mutual social interaction between employees and management. The form of interaction is based on the sense of trust among employees who are rooted in an organizational culture and social ethics. Because there is a sense of trust then arise an employee entity who have togetherness about the values of honesty, discipline, togetherness, and the importance of hard work-savvy.

Transformational leadership in top management tends to stimulate its employees to accelerate the social capital structure in the form of developing a shared vision. In addition, such leadership affects the formation of mutual trust among employees. Thus the harmonious relationship among employees becomes a very important social capital in building an effective working team and able to improve the performance of employees and organizations. Social relations between employees formed by employees both within the organization and outside the organization between employees with social environment is believed to be able to create social capital for employees individually. Because organizations can invest strategically on employees as members of the organization, and communicate a message that affects their desire to jointly contribute to building the organization grow and develop.

Putnam's definition of social capital in 1996 stated that social capital is part of the social lifenetwork, norms and beliefs-that encourage participants to act more effectively together to achieve common goals.

According to Field, Network membership and shared values are at the heart of the concept of social capital. The core idea of social capital theory is that social networks have value, social contacts affect individual and group productivity.According to Fujiwara and Kawachi, social capital is the resources accessed by individuals and groups within a social structure, facilitating cooperation, collective action, and maintaining norms. 
Another dimension related to social capital is the typology of social capital. Social capital can be in the form of bonding or bridging.Putnam termed society with socialcapital bonding as the characteristic of sacred society, that is society which is dominated and survive with totalitarian, hierarchical, and closed society structure by certain dogma. While social capital in the form of bridging is inclusive and outward looking. This social capital turning leads to the search for answers together to solve the problems faced by the group by utilizing the network owned by individuals in the group. Social capital can also have the potential to eliminate conflicts social.Modal social is cumulative and self-increment (self-reinforcing).There are three parameters of social capital, namely trust, norms and networks. Furthermore, Putnam added that social networks are also a channel of information useful for the achievement of individual or group goals. Social capital also has a positive impact on mental health because the social networks owned by individuals are a protector of life's problems. Social capital can maintain social norms within a community and reduce the tendency of selfish behavior among group members.

According to Hasbullah, there are six main elements in social capital based on various existing social capital understanding: participation in network, reciprocity, trust, social norm, values and proactive actions.

It can therefore be synthesized that social capital is a part of social life that affects individual productivity, facilitates cooperation and maintains normas that encourages participants to act together more effectively to achieve common goals. The significant indicators of social capital are:

1) Dimension of Trust (trust); The indicators are: honesty and integrity

2) Social Normal Dimension; The indicators are: rules and reciprocity

3) Network Dimensions; The indicators are: personal contacts and social clicks.

\section{Performance (X4)}

According Wibowo, performance is about doing the job and the results achieved from the job. Performance is about what to do and how to do it. Performance is determined by the objectives to be achieved and to do so required the motive. But performance requires the support of facilities, competencies, opportunities, standards and feedback.Sedarmayanti argues that performance is defined as a record of the outcomes generated from a particular activity, over a period of time.

Rivai explains that performance is a real behavior that everyone displays as work performance generated by employees in accordance with its role in the company. Performance appraisal is a formal and structured system used to measure, assess and influence the properties related to work, behavior and results, including absenteeism.According to Harvard Business Essentials, performance appraisal is a formal method for measuring how well individual workers do the work in relation to the goals given. Armstrong explained that assessment is an opportunity to see thoroughly the content of work, load and volume, reconsider what is achieved during the reporting period and agree on the next objective.

A.A.Anwar Prabu Mangkunegara states the term performance is derived from the words Job Performance or Actual Performance (actual performance or achievement achieved by someone). Performance (work performance) is the work of quality and quantity achieved by an employee in performing their duties in accordance with the responsibilities given to him. Factors that affect the achievement of performance is a factor of ability (ability) and motivation factor (motivation).

Rivai also explained that the usefulness of performance appraisal is viewed from various perspective of organizational development, especially human resource management, namely: bargaining position, performance improvement, compensation adjustment, placement decision, training and development, career planning and development, staffing process evaluation, to overcome external challenges.It can be synthesized that the definition of performance is about doing work and results achieved by employees in doing their work as performance in a certain period of time in quality and quantity according to its role in the organization in an effort to achieve organizational 
goals. The indicators used in the assessment of employee performance are as follows: the work, loyalty (loyalty), responsibility, and discipline.

\section{METHOD}

This research is a quantitative research with unit analysis of Mercu Buana University, using Path Analysis method, with a population of 344 employees. This research uses Slovin formula to determine the number of samples, as follows:

$$
\mathrm{n}=\frac{N}{1+N e^{2}}
$$

Description:

$\mathrm{n}=$ Sample Size

$\mathrm{N}=$ Population Size

$\mathrm{e}=$ leniency due to intolerable sampling error.

The limit of this tolerable error for the population is $5 \%$. So the sample size is 185 . The data in this study include data from Competence (X1), Transformational Leadership (X2), Social Capital (X3), Performance (X4) and Career Employee (X3) Y).

For analytical purposes, quantified data in the form of numbers or scores with Likert scale will be answered by the respondent to test the hypothesis. The sampling technique used is Simple Random Sampling.

\section{Validity and Reliability}

\section{RESULT AND DISCUSSION}

At the trial stage the instrument was taken 30 (thirty) respondents. Test the validity of research instrument instrument aims to see the description of the validity of each research instrument instrument using Pearson Product Moment Correlation Test. Empirically in the test of this instrument, the level of significance is set at $\alpha=0.05$, with the sample number 30 then the degrees of freedom are 28. Referring to these two reference numbers, the valid limit of a item in the list of reference tables (Table $r$ ) is 0.361 . If a item has a value of $r \gg>r$ table, it is declared valid, and vice versa if $r$ arithmetic $<r$ table, it is declared invalid, so the invalid item is dropped or is considered void.

Table 4.1. Validity and Reliability Test Results

\begin{tabular}{|l|c|c|c|c|}
\hline \multirow{2}{*}{ Variable } & \multicolumn{2}{|c|}{ Validity Test Results } & \multicolumn{2}{c|}{ Reliability Test Results } \\
\cline { 2 - 5 } & $\begin{array}{c}\text { Valid } \\
\text { Questions }\end{array}$ & $\begin{array}{c}\text { Invalid } \\
\text { Question }\end{array}$ & $\begin{array}{c}\text { Alpha Cronbach } \\
\text { Value }\end{array}$ & $\begin{array}{c}\text { Assumption of } \\
\text { Reliability }\end{array}$ \\
\hline Competence & 19 & 1 & 0.904 & Perfect \\
\hline $\begin{array}{l}\text { Transformational } \\
\text { leadership }\end{array}$ & 15 & 1 & 0.934 & Perfect \\
\hline Social Capital & 17 & 2 & 0,751 & High \\
\hline Performance & 13 & 1 & 0.900 & Perfect \\
\hline Employee Career & 12 & 0 & 0.856 & Perfect \\
\hline
\end{tabular}

Based on Table 4.1, it can be seen that all variables have a value of Cronbach's alpha> rtable, so all variables is declared reliable and can be forwarded for data collection.

\section{Galat Normality Test}


In this research, Galat Normality Test using Liliefors Method. A normality test is used to determine whether sample data has been drawn from a normally distributed population if $\mathrm{L}_{\text {count }}$ maximum $<\mathrm{L}_{\text {table. }}$ The standard error normality test results in this study are summarized in the following table:

Table 4.2. Recapitulation of Test Result of Estimated Normality Error

\begin{tabular}{|l|l|c|c|c|c|c|}
\hline \multirow{2}{*}{ No } & Regression Estimate & \multirow{2}{*}{$\mathbf{n}$} & \multirow{2}{*}{ L.Table } & \multicolumn{2}{|c|}{ L.Count } & \multirow{2}{*}{ Description } \\
\cline { 4 - 6 } & Error & & $\mathbf{a = 5 \%}$ & $\mathbf{a = 1 \%}$ & \\
\hline 1 & $\mathrm{X} 4$ on X1 & 185 & 0,054 & 0,065 & 0,076 & Normal \\
\hline 2 & $\mathrm{X} 4$ on X2 & 185 & 0,049 & 0,065 & 0,076 & Normal \\
\hline 3 & $\mathrm{X} 4$ on X3 & 185 & 0,061 & 0,065 & 0,076 & Normal \\
\hline 4 & Y on X1 & 185 & 0,059 & 0,065 & 0,076 & Normal \\
\hline 5 & Y on X3 & 185 & 0,047 & 0,065 & 0,076 & Normal \\
\hline 6 & Y on X4 & 185 & 0,050 & 0,065 & 0,076 & Normal \\
\hline
\end{tabular}

\section{Linierity and Significant Test}

Linearity test and regression significance is done by using SPSS software version 21. From SPSS output. The constants and coefficients of the linear regression equation are obtained from column B in the Coefficients table. and positive influence seen from table Anova in column F where Fhitung $>$ Ftabel and value of significance p-value $<0,05$.

The linearity test of the regression equation is determined based on the ANOVA Table where the relationship between variables meets the linear assumption if the Deviation From Linierity value Fcount $<$ Ftable and the value of $\mathrm{p}$-value $>0.05$ then the regression equation is linear.

Table 4.3. Linierity Test Results and Regression Significance

\begin{tabular}{|l|c|c|c|c|c|c|c|}
\hline \multirow{2}{*}{ Variable } & \multicolumn{3}{|c|}{ Linearity Test } & Linierity & \multicolumn{2}{c|}{ Significance Test } & Significant \\
\cline { 2 - 3 } & $\mathbf{F}_{\text {Count }}$ & $\mathbf{F}_{\text {table }}$ & Sig. & Result & $\mathbf{F}_{\text {hitung }}$ & $\mathbf{F}_{\text {table }}$ & Result \\
\hline X1 to Y & 1,507 & 1,62 & $0,81>0,05$ & Linier & 178,703 & 3,89 & Significant \\
\hline X4 to Y & 1,146 & 1,65 & $0,31>0,05$ & Linier & 212,961 & 3,89 & Significant \\
\hline X3 to Y & 1,328 & 1,60 & $0,157>0,05$ & Linier & 155,823 & 3,89 & Significant \\
\hline X1 to X4 & 1,081 & 1,62 & $0,374>0,05$ & Linier & 150,560 & 3,89 & Significant \\
\hline X2 to X4 & 1,176 & 1,64 & $0,281>0,05$ & Linier & 94,362 & 3,89 & Significant \\
\hline X3 to X4 & 1,078 & 1,60 & $0,375>0,05$ & Linier & 121,392 & 3,89 & Significant \\
\hline
\end{tabular}

\section{Research Result}

There are 2 models of influence structure tested in this research, that is:

a). Substructure 1 : Y On $\mathrm{X}_{1} \mathrm{X}_{3} \mathrm{X}_{4}$ (Y.134)

Table 4.4Coefficient Sub Structure 1

Coefficients $^{\mathrm{a}}$

\begin{tabular}{|l|c|c|c|c|c|}
\hline \multirow{2}{*}{ Model } & \multicolumn{2}{|c|}{ Unstandardized Coefficients } & $\begin{array}{c}\text { Standardized } \\
\text { Coefficients }\end{array}$ & \multirow{2}{*}{ T } & \multirow{2}{*}{ Sig. } \\
\cline { 2 - 4 } & B & Std. Error & Beta & & \\
\hline \multirow{2}{*}{ (Constant) } & $-3,521$ & 2,561 & & $-1,375$ &, 171 \\
1 X1 &, 172 &, 047 &, 258 & 3,650 &, 000 \\
X3 &, 158 &, 047 &, 229 & 3,391 &, 001 \\
X4 &, 354 &, 053 &, 416 & 6,636 &, 000 \\
\hline
\end{tabular}

a. Dependent Variable: Y

$\alpha=0.05$ and the value of $t$ table $=1.97$, then the test results of all paths in sub-structure 1 is significant.

Table 4.5.Model Summary Sub Structure 1 
Model Summary

\begin{tabular}{|l|r|r|r|r|}
\hline Model & $\mathrm{R}$ & R Square & $\begin{array}{c}\text { Adjusted } \mathrm{R} \\
\text { Square }\end{array}$ & $\begin{array}{c}\text { Std. Error of the } \\
\text { Estimate }\end{array}$ \\
\hline 1 &, $801^{\mathrm{a}}$ &, 641 &, 635 & 2,172 \\
\hline
\end{tabular}

\section{a. Predictors: (Constant), $\mathrm{X} 4, \mathrm{X} 3, \mathrm{X} 1$}

Based on the calculation of SPSS in Table 4.5, it appears that the coefficient of determination sub structure $1(\mathrm{R} 2 \mathrm{Y} .134)=0.641$, so that $\varepsilon \mathrm{Y}=1-\mathrm{R} 2=1-0.641=0.36$.

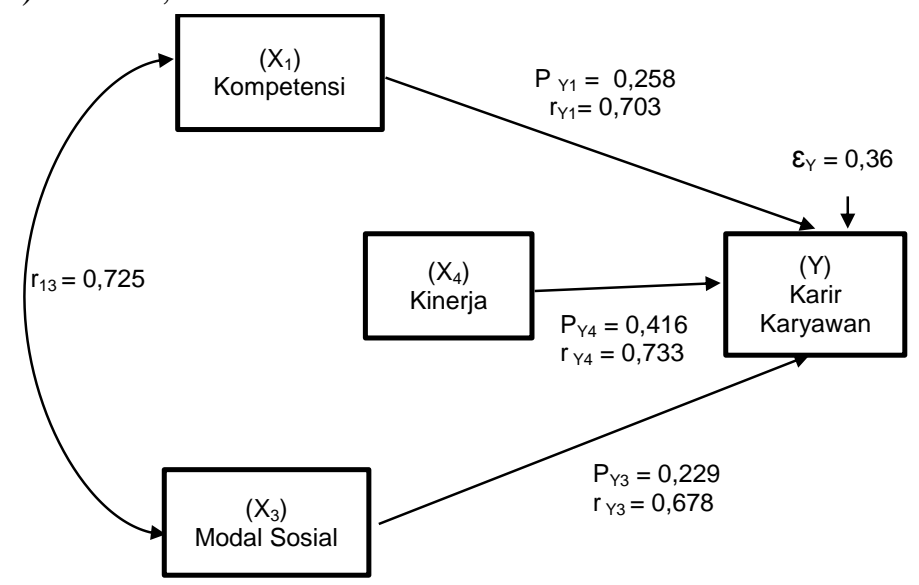

Figure 2. Emprical Model Sub Structure 1

b). Substructure $2: \mathrm{X}_{4} \mathrm{On} \mathrm{X}_{1} \mathrm{X}_{2} \mathrm{X}_{3}(\mathrm{X} 4.123)$

Table 4.6. Coefficient Sub Structure 2

Coefficients $^{\mathrm{a}}$

\begin{tabular}{|l|c|c|c|c|c|}
\hline \multirow{2}{*}{ Model } & \multicolumn{2}{|c|}{ Unstandardized Coefficients } & $\begin{array}{c}\text { Standardized } \\
\text { Coefficients }\end{array}$ & \multirow{2}{*}{ T } & \multirow{2}{*}{ Sig. } \\
\cline { 2 - 4 } & B & Std. Error & Beta & & \\
\hline \multirow{2}{*}{ (Constant) } & 6,081 & 3,540 & & 1,718 &, 088 \\
1 X1 &, 297 &, 062 &, 378 & 4,825 &, 000 \\
X2 &, 200 &, 065 &, 213 & 3,100 &, 002 \\
X3 &, 183 &, 064 &, 226 & 2,860 &, 005 \\
\hline
\end{tabular}

a. Dependent Variable: X4

At $\alpha=0.05$ and the value of $t$ table $=1.97$, then the test results of all paths on sub-structure 2 is significant.

Tabel 4.7. Model Summary Sub Structure 2

Model Summary

\begin{tabular}{|l|r|r|r|r|}
\hline Model & $\mathrm{R}$ & $\mathrm{R}$ Square & \multicolumn{1}{c|}{$\begin{array}{c}\text { Adjusted R } \\
\text { Square }\end{array}$} & $\begin{array}{c}\text { Std. Error of the } \\
\text { Estimate }\end{array}$ \\
\hline 1 &, $722^{9}$ &, 521 &, 513 & 2,952 \\
\hline
\end{tabular}

a. Predictors: (Constant), $\times 3, \times 2, \times 1$

Based on the calculation of SPSS in Table 4:37, it appears that the coefficient of determination sub structure $2(\mathrm{R} 2 \mathrm{X} 4.123)=0,521$, so that $\varepsilon X 4=1-\mathrm{R} 2=1-0.521=0.48$. 


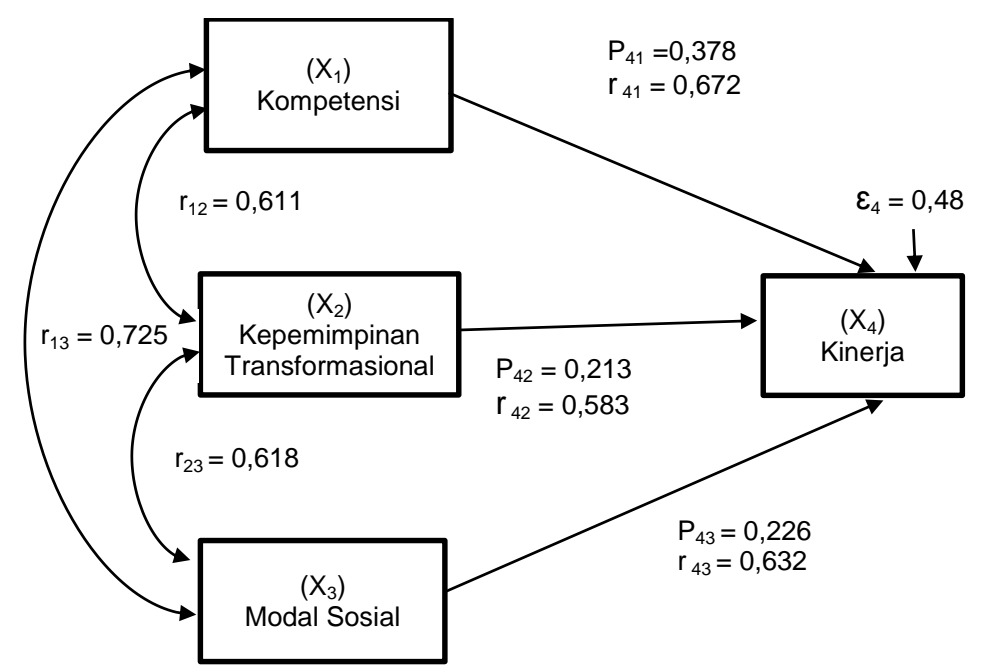

Figure 3. Emprical Model Sub Structure 2

Furthermore, the path analysis yields a structural equation as follows:

$$
\begin{aligned}
& \mathrm{Y}=\mathrm{PYX}_{1}+\mathrm{PX}_{4} \mathrm{X}_{2}+\mathrm{PYX}_{3}+\mathrm{PYX}_{4}+\varepsilon_{\mathrm{Y}} \\
& \mathrm{Y}=0,258 \mathrm{X}_{1}+0,213 \mathrm{X}_{2}+0,229 \mathrm{X}_{3}+0,416 \mathrm{X}_{4}+0,36
\end{aligned}
$$

Based on the above structural model can be explained that the most direct influence on Employee Career is a Performance variable of $41.6 \%$, while the variable Competence of $25.8 \%$ and social capital variable of $22.9 \%$. The independent variable that has the strongest influence on the Performance is a Competence variable of $37.8 \%$ while the Transformational Leadership variable of $21.3 \%$ and social capital variable of $22.6 \%$.

\section{CONCLUSSION}

The conclusion of the results of this study is:

Competence has a direct positive effect on the Employee Career.Employees pro-active need to improve their competence by doing self-development and skills.Because of the educational level it is a condition for getting promoted in their work. Employees need to be flexible to the dynamics of work and quickly adapt in order to get the job done properly.

Performance has a direct positive effect on the Employee Career.Employees need to show high performance, loyalty and responsible in their work as an effort to improve their career.

Social Capital has a direct positive effect on the Employee Career.If the employee wants to have a good career at Mercu Buana University then the employee can maximize the relationship of his social network or social capital to get information about matters related to experience in solving problems in the job as well as information about work operations and opportunities in the work both internally and external organizations, making it easier for employees in completing their work and able to compete according to the required qualifications.

Competence has a positive direct effect on Performance.If the employee wants to have high performance then it is necessary to improve the Competency both hardskill and softskill.

Transformational leadership has a direct positive effect on Performance.The leaders of the University of Mercu Buana sometimes present challenges to motivate their employees more creatively in accomplishing their work and performing high but not deviating from the prevailing rules. Leaders regularly evaluate existing procedures and even internal audit per 3 months as a management controlling function.

Social Capital has a direct positive effect on Performance.If employees want to have good performance then employees need to build their Social Capital. Employees can utilize the social capital they have to share their knowledge through personal interaction and teamwork by building positive communication. 


\section{REFRENCES}

Agusyanto, Ruddy. (2014).Jaringan Sosial dalam Organisasi. Jakarta: Rajawali Pers.

Amalia, Ayu Diah. (2015).Modal Sosial dan Kemiskinan, Sosio Informa Vol. 1, No. 03, September Desember.

Arifin, Noor. (2013).Pengaruh Ukuran Organisasi \& Politicking Terhadap Kinerja dan Pengembangan Karir, Jurnal Economia, Volume 9, Nomor 2, Oktober.

Atma Negara, Ni Made Candra Megita. (2014).Pengaruh Pengembangan Karir Terhadap Kinerja Pegawai Pada Pt. Pos Indonesia (Persero) Kabupaten Jembrana. http://ejournal.undiksha.ac.id/index.php/JJPE/article/viewFile/4517/3484 (diakses tgl. 22 Juni 2016)

Atmojo, Marnis. (2012).The Influence of Transformational Leadership on Job Satisfaction, Organizational Commitment, and Employee Performance, International Research Journal of Business Studies, Vol. V (02).

Bellé, Nicola. (2013). Leading to Make a Difference: A Field Experiment on the Performance Effects of Transformational Leadership, Perceived Social Impact, and Public Service Motivation, Journal of Public Administration Research and Theory.

Bahri, Samsul. (2016).Pengaruh Pengembangan Karier Dan Kompetensi Terhadap Produktivitas Kerja Serta Implikasinya Pada Kinerja Pegawai Dinas Pu Bina Marga Wilayah Kerja Sumatera Selatan, Jurnal EComent Global, Volume 1 Nomor 1 Edisi. ISSN: 2540-816X

Bernardin, et al. (2013).Human Resource Management: Experimental Approach. Singapore: McGraw-Hill, Inc.

Brian Aprinto, Fonny Arisandy Jacob. (2013).Pedoman Lengkap Profesional SDM Indonesia, PPM Manajemen, Jakarta.

Carter, Min Z., Achilles A. Armenakis, Hubert S. Feild and Kevin W. Mossholder. (2013).Transformational Leadership, Relationship Quality, and Employee Performance during Continuous Incremental Organizational Change, Journal of Organizational Behavior, Vol. 34 (7).

Cooper, Donald R., Pamela S. Schindler. (2013).Business Research Methods. Singapore: McGrawHill.

Dandy Rahman, Sri Wahyu Lely, Chairul Soleh. (2017).Pengaruh Kompetensi dan Kepemimpinan Terhadap Kinerja Karyawan Dengan Motivasi Sebagai Variabel Intervening (Studi Kasus Pada Karyawan Bagian Pabrik PT.Jember Indonesia), Artikel Ilmiah Mahasiswa 2014. repository.unej.ac.id/bitstream/handle/123456789/63998/Dandy\%20Rahman.pdf?sequence= 1 diakses 27 Mei.

Dewi, I.A.Putu Kartika, I Gede Riana. (2015).Pengaruh Penilaian Kinerja dan Pengalaman Kerja Terhadap Pengembangan Karir Pada Pt Bali Biasa Indah Koleksi Kuta - Bali, E-Jurnal Manajemen Unud, Vol. 4, No. 7: 1918-1933 ISSN: 2302-8912.

Egota, Depri Egota, Endang Sutrisna. (2015).Analisis Faktor-faktor yang Mempengaruhi Pengembangan Karir Karyawan Pada PT. Bank Negara Indonesia (Persero), Tbk Cabang Pekanbaru, Jom FISIP Volume 2 No.1 - Februari.

Faisal, Sanapiah. (2010).Format-format Penelitian Sosial. Jakarta: Rajawali Press.

Fauzan, Mohammad. (2012).Peningkatan Kinerja Dosen Berbasis Modal Sosial dan Dukungan Organisasional Di PTS Kota Semarang, Jurnal Bisnis dan Ekonomi (JBE), September. Hal. 188 - 202 Vol. 19, No. 2, ISSN: 1412-3126

Field, John. (2014). Modal Sosial. Bantul: Kreasi Wacana Offset.

Hadian, Dedi., Yani Suharyani. (2014).Pengaruh Motivasi, Komunikasi dan Kompetensi Dari Efektivitas Kinerja Aparatur Serta Dampaknya Terhadap Efektivitas Organisasi Badan Koordinasi Promosi dan Penanaman Modal Daerah Provinsi Jawa Barat, Jurnal Ekonomi, Bisnis dan Enterpreneurship, Vol.8, No.1, April, 1-14, ISSN : 2443-0633

Hermawan, Decky. (2009). Lembaga Pendidikan Perlu Kepemimpinan Transformasional. Jurnal Educare, No.11.

Hudaykulov, Akmal., Xu Hongyi. (2015).The Effects Of Social Capital On Team Performance:A Study Of RD Departments In Uzbekistan, International Journal of Management Science and Business Administration, Volume 1, Issue 1, April.

Hughes, Richard. Gimmet, Robert. Curphy, Gordon. (2012).Leadership, Enhancing The Lessons of Experience. New York: McGraw Hill, USA. 
Human Capital Journal No.23 Tahun II, hal.11. http://humancapitaljournal.com/data/wpcontent/uploads/2015/02/HCJ-23-edisi-Mei-2013-cvr-story-spread.pdf diakses tgl. 16 Mei 2017

Hutapea, Parulian, Nurianna Thoha. (2008). Kompetensi Plus, Teori, Desain, Kasus dan Penerapan untuk HR dan Organisasi yang Dinamis. Jakarta: PT. Gramedia.

Http://www.bppk.kemenkeu.go.id/publikasi/artikel/168-artikel-pengembangan-sdm/10861hubungan-antara-kepemimpinan-transformasional-budaya-organisasional-komunikasiorganisasi-terhadap-kinerja-pegawai, diakses tgl. 21 Juni 2016

Ivancevich, John M., Robert Konopaske. (2013).Human Resource Management. Mc Graw-Hill International Edition.

Kadir. (2015).Statistika Terapan. Jakarta: Rajawali Press.

Kristyanto, Anang. (2008).Pengaruh Modal Sosial Terhadap Kesuksesan Karir Manajer, Jurnal Manajemen, Akuntansi dan Bisnis, Volume 6 No.1, April 2008, ISSN: 1693-252X. Terakreditasi SK Dirjen Dikti No.26/DIKTI/Kep/2006.

Kusumastuti, Ayu. (2015).Modal Sosial dan Mekanisme Adaptasi Masyarakat Pedesaan dalam Pengelolaan dan Pembangunan Infrastruktur, MASYARAKAT: Jurnal Sosiologi, Vol. 20, No. 1, Januari.

Komang Ade Yunita Sari, Wayan Gede Supartha, I Gede Riana. (2017). Pengaruh Kepemimpinan Transformasional Terhadap Kepuasan Kerja dan Komitmen Organisasional (Studi di Perusahaan Daerah Pasar Kota Denpasar), E-Jurnal Ekonomi dan Bisnis Universitas Udayana 6.1

Makawi, Umar, Normajatun, Abdul Haliq. (2015). Analisis Pengaruh Kompetensi Terhadap Kinerja Pegawai Dinas Perindustrian Dan Perdagangan Kota Banjarmasin, Jurnal Al - Ulum Ilmu Sosial Dan Humaniora ISSN: 2476 - 9576 Volume 1 Nomor 1, Oktober.

Mangkunegara, A.A Anwar Prabu. (2011). Manajemen Sumber Daya Manusia Organisasi.Bandung: PT. Remaja Rosdakarya.

Mankunegara, Anwar Prabu. (2012).Evaluasi Kinerja SDM, cetakan keenam. Bandung: Refika Aditama.

Mangkuprawira,Tb.Sjafri,https://ronawajah.wordpress.com/2009/1 1/15/pentingnya-modal-sosialdalam-organisasi/sosial-dalam-organisasi/, diakses tgl.24 Juni 2016

Manopo, Christine(2011).Competence Based Talent and Performance Management System. Jakarta: Salemba Empat.

Marwansyah. (2012). Manajemen Sumber Daya Manusia. Bandung: Alfabeta.

Meriam Ali, Siti.,Mohd Rizaimy Shaharudin., Azyyati Anvar. (2012). The Association Between Job Positions, Work Experience And Carrer Satisfaction : The Case Of Malaysian's Academic Staff. Asian Social Science. 6(10).

Moeheriono. (2012).Pengukuran Kinerja Berbasis Kompetensi. Jakarta: Rajawali Press.

Mukhtar, Hapzi Ali, Siti Raudhatul Jannah. (2016). Analysis of Leadership Style and Organizational Culture Effect on Career Development at Ministry Religious Affairs in Jambi Province, IOSR Journal of Business and Management (IOSR-JBM), e-ISSN: 2278-487X, pISSN:2319-7668. Volume 18, Issue 11. Ver:IV (November 2016), PP65-74. www.iosjournals.org

Mulla, Zubin R., Venkat R. Krishnan. (2011).Transformational Leadership: Do the Leader's Morals Matter and Do the Follower's Morals Change?, Journal of Human Values, Vol. 17 (2).

Njagi, Lucy Karimi. (2012).Relationship Between Social Capital And Employee Promotion, International Journal of Business and Commerce Vol. 1, No.10: Jun 2012 [01-13] (ISSN: 2225-2436), www.ijbcnet.com.

Ngadimin, Wuradji. (2014).Pengaruh Kepemimpinan Transformasional Kepala Sekolah, Motivasi Kerja, Dan Kedisiplinan Terhadap Pengembangan Karir Guru SD, Jurnal Akuntabilitas Manajemen Pendidikan, Volume 2, Nomor 2.

Ni Luh Putu Sukmayanti, I Wayan Bagia, I Wayan Suwendra. (2016). Pengaruh Kompetensi Intelektual dan Pengembangan Karir Karyawan Terhadap Kinerja Karyawan, e-Journal Bisma Universitas Pendidikan Ganesha Jurusan Manajemen, Volume 4 tahun 2016, http://www.e-jurnal.com/2016/03/pengaruh-kompetensi-intelektual-dan.html diakses tanggal 16 Mei 2017.

Noe, Raymond A., et al. (2010). Manajemen Sumber Daya Manusia. McGraw-Hill. 
Noviarista, Helfiana. (2015). Pengaruh Persepsi Guru Tentang Kepemimpinan Transformasional Kepala Sekolah Terhadap Kompetensi Profesional Dan Kinerja Guru, Jurnal Pendidikan Guru Sekolah Dasar Edisi 1 Tahun ke 1V Januari.

Paracha, M. Umer, Adnan Qamar, Anam Mirza, Inam-ul-Hassan and Hamid Waqas. (2012). Impact of Leadership Style (Transformational \&Transactional Leadership) on Employee Performance \& Mediating Role of Job Satisfaction: Study of Private School (Educator) in Pakistan, Global Journal of Management and Business Research, Volume 12 (4).

Rahel Widiawati Kimbal. (2015).Modal Sosial dan Ekonomi Industri Kecil Sebuah Studi Kualitatif. Yogyakarta: CV Budi Utama.

Renowati. (2013).Jaringan Sosial Gereja Kristen Jawi Wetan (GKJW) dengan Pondok Pesantren Di Malang Jawa Timur, Jurnal Analisa Pengkajian Masalah Sosial Keagamaan, (Volume 20 Nomor 01 Juni.

Rivai, Veithzal. (2009).Manajemen Sumber Daya Manusia untuk organisasi: dari Teori ke Praktik. Jakarta: Raja Grafindo Persada.

Rivai, Veithzal. (2013). Manajemen Sumber Daya Manusia Untuk Organisasi: dari Teori ke Praktik. Jakarta: Raja Grafindo Persada.

Salehudin, Imam. (2010).Invest In Yourself: Aplikasi Konsep Human Capital dari Sudut Pandang Karyawan. Manajemen Usahawan Indonesia, No. 06/TH. XXXIX 2010. ISSN: 0302-9859

Sedarmayanti. (2014).Manajemen Sumber Daya Manusia: Reformasi Birokrasi dan Manajemen Karyawan Negeri Sipil. Bandung: PT. Refika Aditama.

Shaputra, Angga Rahyu, et al. (2015).Pengaruh Kompetensi, Komitmen Dan Pengembangan Karir Terhadap Kinerja Karyawan Pt. Bank Rakyat Indonesia (Persero) Kantor Wilayah Pekanbaru, Vol VII No 1 Januari 2015 Jurnal Tepak Manajemen Bisnis.

Sicilia, Gita, Marzolina. (2015).Pengaruh Kepemimpinan, Pengembangan Karir dan Motivasi Terhadap Kepuasan Kerja Karyawan Bank Riau Kepri Cabang Utama Pekanbaru, Vol VII No 1 Januari 2015 Jurnal Tepak Manajemen Bisnis.

Sinambela, Lijan Poltak. (2016).Manajemen Sumber Daya Manusia. Jakarta: Bumi Aksara.

Sudarmanto. (2009).Kinerja dan Pengembangan Kompetensi SDM: Teori, Dimensi Pengukuran dan Implementasi dalam Organisasi. Yogyakarta: Pustaka Belajar.

Suhar Janti. (2015). Analisis Validitas dan Reliabilitas Dengan Skala Likert Terhadap Penerapan Strategic Planning Sistem Informasi Garmen: Studi Kasus PT. Asga Indocare, Seminar Nasional Inovasi dan Trend (SNIT), Proceedings SNIT.

Sukmayanti, Ni Luh Putu,et al. (2016).Pengaruh Kompetensi Intelektual Dan Pengembangan Karir Karyawan Terhadap Kinerja Karyawan, e-Journal Bisma Universitas Pendidikan Ganesha Jurusan Manajemen, Volume 4.

Sunyoto, Danang. (2015). Teori, Kuesioner, dan Analisis Data Sumber Daya Manusia. Yogyakarta: CAPS.

Sutrisno, Edi. (2009).Manajemen Sumber Daya Manusia, Edisi pertama. Jakarta: Kencana Prenada Media Group.

Sutrisno, Edy. (2012).Manajemen Sumber Daya Manusia. Prenadamedia Grup.

Sutrisno, Edy. (2016).Manajemen Sumber Daya Manusia. Prenadamedia Grup.

Suparno Eko Widodo. (2015).Manajemen Pengembangan Sumber Daya Manusia. Pustaka Pelajar.

Thobias, Erwin, A.K.Tungka, J.J. Rogahang. (2013).Pengaruh Modal Sosial Terhadap Perilaku Kewirausahaan, Journal "ACTA DIURNA" Edisi April.

Tims, Maria, Arnold B. Bakker, and Despoina Xanthopoulou. (2011). Do Transformational Leaders Enhance Their Followers' Daily Work Engagement, The Leadership Quarterly, Volume 22 (1).

Universitas Mercu Buana, http://www.mercubuana.ac.id/id/tentang-umb/visi-dan-misi, (diakses $\operatorname{tg} 1.21$ Juni 2016)

Vivin Lian Hutajulu. (2015). Pengaruh Penilaian Kinerja Dan Pengalaman Kerja Terhadap Pengembangan Karir Pada Pt Bali Biasa Indah Koleksi Kuta - Bali, 2015, ThesisFakultas Ekonomi Dan Manajemen, Institut Pertanian Bogor

Wardianto, M., Fabiola Hendrati. (2014).Korelasi Motivasi Berprestasi Dan Kepemimpinan Transformasional Dengan Komitmen Organisasi Pengurus Pondok Pesantren, Persona, Jurnal Psikologi Indonesia September 2014, Vol. 3, No. 03.

Wibowo. (2014).Manajemen Kinerja. Jakarta: Rajagrafindo. 
Widyatmini, Luqman Hakim. (2008).Hubungan Kepemimpinan, Kompensasi Dan Kompetensi Terhadap Kinerja Pegawai Dinas Kesehatan Kota Depok, Jurnal Ekonomi Bisnis No. 2 Vol. 13 ,

Agustus, hal.

$163-$ 170,http://ejournal.gunadarma.ac.id/index.php/ekbis/article/viewFile/308/247 diakses tgl. 3 November 2016.

Wilkins, David, Greg Carolin. (2013).Leadership Pure and Simple, How Transformaive Leaders Create Winning Organizaions. USA: McGraw Hill.

Yukl, Gary. (2012).Kepemimpinan Dalam Organisasi, Edisi Kelima. Jakarta: PT. Indeks.

Yukl, Gary. (2011).Kepemimpinan Dalam Organisasi; Alih Bahasa : Budi Supriyanto. Jakarta : PT. Indeks.

Zafra, Esther Lopez, Rocio Garcia-Retamero and M. Pilar Berrios Martos. (2012). The Relationship between Transformational Leadership and Emotional Intelligence from a Gendered Approach, The Psychological Record, Vol. 62 (1).

Zahreza Fajar Setiara Putra, Mohammad Sholeh, Naniek Widyastuti. (2014). Analisis Kualitas Layanan Website Btkp-Diy Menggunakan Metode Webqual 4.0, Jurnal JARKOM Vol. 1 No. 2 Januari 2014 ISSN:2338-6312

Zakiyah, Eny Ariyanto. (2016). Analisis Pengaruh KompetensiTerhadapKinerjaKaryawan Badan Pengelola Dan Pengembangan Taman Mini Indonesia Indah, Jurnal Akuntansi dan Manajemen 2016, http://manajemen.upy.ac.id/manajemen/wpcontent/uploads/2016/12/Zakiyah-Analisis-Pengaruh-Kompetensi-Terhadap-KinerjaKaryawan-Badan-Pengelola-Dan-Pengembangan-Taman-Mini-Indonesia-Indah.pdf diakses tgl. 16 Mei 2017. 